\section{Eucalyptus forestry in Brazilian Pampa biome: between developmental illusion and sustainable inefficacy}

\author{
Jefferson Marçal da Rocha I; Nájila Souza da Rocha II; Pâmela Suélen Käfer III; \\ Rafael Cabral Cruz IV
}

\begin{abstract}
The objective of this article is to analyze how the strategy for the implementation of eucalyptus monoculture in the Brazilian pampa Biome had repercussions on economic, social and environmental aspects. It makes a historical rescue of the formation of the economic development of the region, noting that the forestry project for the region has not escaped the expectations of other strategies imposed on the region in the past, the concentration of wealth of the agrarian elite has never been threatened. Extensive livestock farming, until the beginning of the 20th century, grain monoculture, after World War II, and from the 2000s, forestry, have always been linked to a single logic: the accumulation of capital in the hands of the bourgeoisie. The most aggravating factor in eucalyptus production is the mischaracterization of the Pampa biome, which the richness of this ecosystem, even though it requires better studies, is not taken into account in the policy of forestry expansion. For a legitimate development process is necessary to find endogenous mechanisms to promote development compatible with the improvement of the poorest population and the maintenance of the wealth of the Pampa biome. Factors disregarded in the developmental alternatives proposed for the region to date.
\end{abstract}

Keywords: Monoculture; Sustainable Development; Capitalism

\footnotetext{
I Universidade Federal do Pampa, São Gabriel, Brazil. jeffersonmrocha@gmail.com

II Universidade Federal do Rio Grande do Sul, Porto Alegre, Brazil. najila.rocha@ufrgs.br

III Universidade Federal do Rio Grande do Sul, Porto Alegre, Brazil. pamelaskafer@gmail.com

Iv Universidade Federal do Pampa, São Gabriel, Brazil. rafaelcabralcruz@gmail.com
} 


\section{INTRODUCTION}

The implementation of eucalyptus monoculture policies in Brazilian Pampa biome, especially in the south of Rio Grande do Sul State (SRS), was constituted through an economic policy strategy. This strategy was mostly articulated by private and public agents during the 2000s, who had the same economics-developmentalist ideological perspective in understanding employment creation and regional development.

The Brazilian commercial purpose was made explicit at the United Nations Conference on Environment and Development, held in Stockholm, 1972. In the occasion José Sarney, a senator from the Northeast of Brazil, who would become president a decade later claimed: "Let pollution come, as long as the factories come with it" (DEAN, 1996, p. 307)

This forest model was proposed not only by SRS, but also Uruguay and northern region of Argentina. Specifically for SRS region, the developmental discourse was strongly enhanced, given the historical economic difference between development indices of the Southern and the Northern region of Rio Grande do Sul State (GAUTREAU, 2014; ROCHA, 2011). The promise propagated by these agents was that SRS should improve its economic performance indicators with the introduction of forestry, dominated for centuries by extensive cattle ranching.

On the other hand, social agents linked to environmental Non-Governmental Organizations (NGOS) reacted to these strategies by condemning the criteria that were considered in encouraging monoculture forestry. These groups, although they took a few months to realize the environmental risk of the proposal, began to vehemently denounce the environmental risk that these large crops would cause in the biodiversity of Pampa Biome.

This paper evaluates how this proposal was constituted as a development project for SRS, as well as its dilemmas and strong limiting factors, with regard to a sustainable strategy to promote regional development in the region. This article is divided into 8 topics: the 1st topic consists of this introduction.

The 2nd tries to understand how the social and economic development of the SRS started, mainly considering the peculiarity of the Pampa biome formation; with this it is considered that this formation should be understood from its biogeographic configuration to the merely productivist use of its natural stocks. 
The 3rd topic analyzes the creation of the SRS economic crisis "discourse", which have always served for the dominant class to establish productive strategies that favored them, since they counted (and still count) with the guarantees of the governments and the endorsement of the poorest classes.

The 4th topic is an analysis of how the implantation of eucalyptus forest latifundios politics was established in the region, which was clearly a structured game of economic and political power, between the great companies of the sector and the state and municipal governments.

In the 5th, an approach is made to the environmental problem that involves this production in the region; the 6th topic is a complement from an accurate analysis of the ecological effects that the expansion of monoculture tree plantations may have on the Pampa biome.

The 7th chapter contains the final considerations, which summarizes and critically analyze the points developed in the article, as well as points out the limitations of this research and themes that can still be developed on the subject, especially a challenge for researchers who are concerned not only about purely economic development strategies, but also with maintaining natural resources nowadays and in the future that may come, if we do not limit ourselves to accepting the perverse logic of irresponsible development. Finally, in the 8th topic there is the reference list cited.

\section{THE BIO-SOCIOECONOMIC FORMATION OF BRAZILIAN PAMPA BIOME}

The SRS region consists of 106 municipalities and is economically characterized by primary activities, as cattle, soybean and rice (ALBUQUERQUE, 2012; ROCHA, 2011). The region is the largest border area of Mercosur and occupies approximately 154 thousand $\mathrm{Km}^{2}$, which represents $52 \%$ of Rio Grande do Sul State. It has a resident population of about 2.6 million inhabitants (IBGE, 2010), which means around 25\% of the State total population (ETGES, 2010).

As Pampa biome is the only large natural area restricted to a single Brazilian state, it is considered a peculiar ecosystem. This biome advances to Uruguay and Argentina (see Figure 1), thus being unique to southern South America (CRUZ; GUADAGNIN, 2010; SANTOS; TREVISAN, 2009). 
Figure 1 - Localization of Pampa biome and South of Rio Grande do Sul State

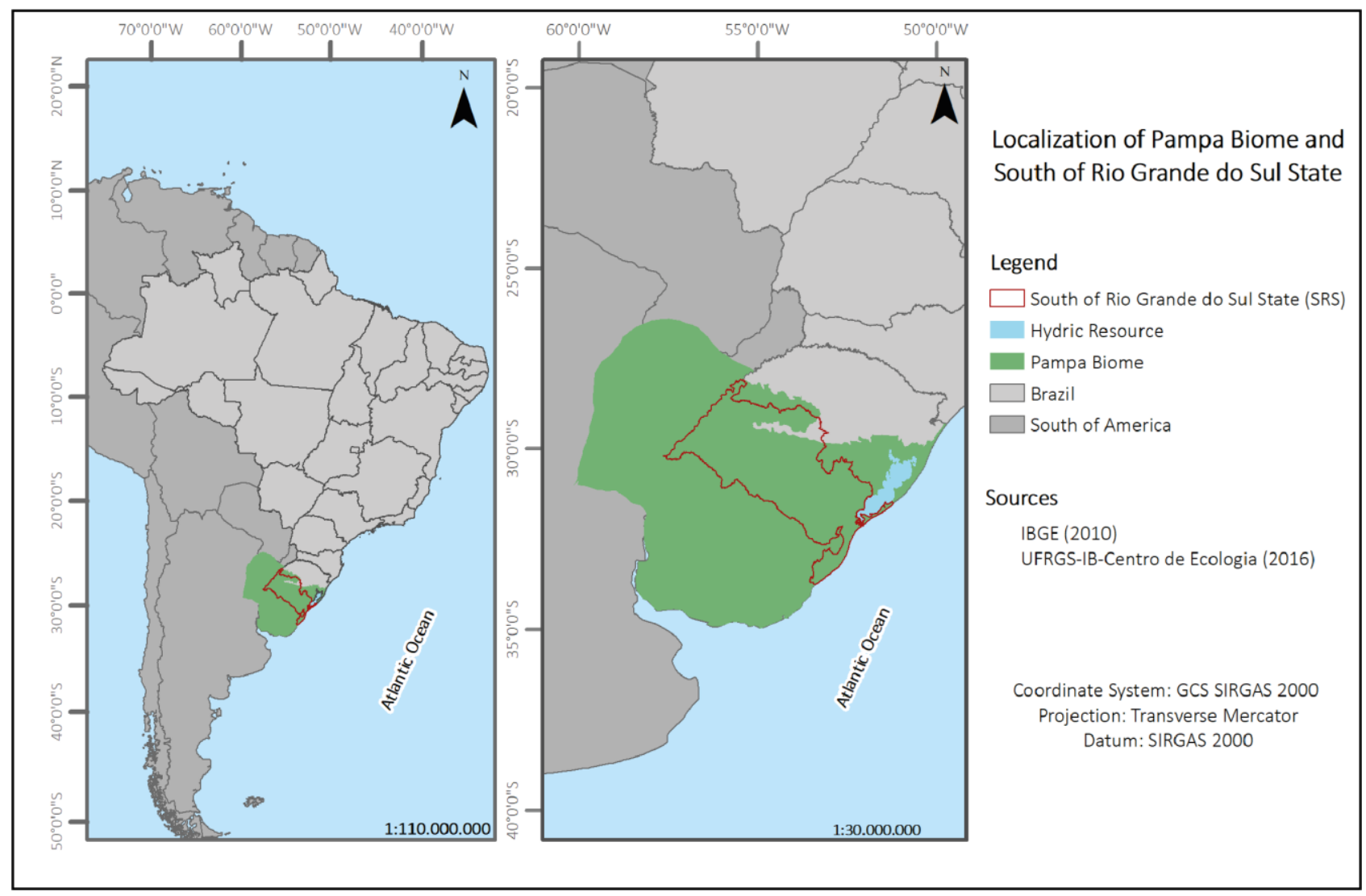

Source: Elaborated by Author. UFRGS-IB-CENTRO DE ECOLOGIA (2016); IBGE (2010).

In Brazil, the Pampa occupies more than 178 thousand Km2, which corresponds to more than $60 \%$ of the Rio Grande do Sul State territory and around $2 \%$ of the whole country. The region is frequently known as an ecologically poor region. Nevertheless, this is information disseminated and propagated by the "common sense". In fact, Pampa is rich in vegetation and fauna, with varied ecosystems, such as capoeiras, "pampa" forests and riparian forests.

According to the Map of Brazilian Biomes, despite Pampa occupying only $2 \%$ of the National territory, is one of the richest in geoecological configuration, mainly because it includes several microecosystems. In addition to the natural grasslands, it has a large variety of species (flora and fauna), which compose a peculiar landscape, said as "a sea of living green" (OVERBECK; PODGAISKI; MÜLLER, 2015; SANTOS; TREVISAN, 2009).

CRUZ and GUADAGNIN (2010) mention that the most important Pampa microecosystems are the wetlands, fundamental for the life reproduction and water cycles regulation and the riparian or gallery forests, which serve as refuge for a diverse fauna. In this context, OVERBECK, PODGAISKI and MÜLLER (2015) point out that once Pampa ecosystems have their own characteristics, the simple quantification of being larger or 
smaller than a tropical forest biodiversity, becomes meaningless. For biodiversity purposes, what matters is the unique and irreplaceable biodiversity of each biome.

The SRS economic development occurred late than the capitalist expansion in other Brazilian and Latin America regions. According to historian PESAVENTO (1992), the Rio Grande do Sul State was discovered at the beginning of the century XVI from coastal expeditions of exploration and trade of redwood (Paubrasilia echinata Lam), typical of the pre-colonizing phase that reached the coast of southern Brazil and was later integrated with the rest of colonial Brazil.

The region remained unexplored for over a century, while in the rest of Portuguese America sugar mills were developed. Disconnected from colonial export agriculture directly integrated with the international market, Rio Grande do Sul State lacked meaning in the context of the primitive capital accumulation process occurred within the Old Colonial System (PESAVENTO, 1992).

From a territorial point of view Pampa biome covers large geographical extensions. These landscapes have a strong cultural appeal that generated the gaucho's culture and established a way of life peculiar to other Brazilian regions, but very close to the Argentine Pampas. (BARCELOS, 2012; SANTOS; TREVISAN, 2009).

One of the main economic activities of Pampa is the extensive cattle raising, which had been the only one for several years (17th century to mid-19th century). Since the soil is not appropriate for intensive farming in most places, this was a consequence of natural conditions. From a socioeconomic point of view, Pampa is characterized by low demographic density and concentrated economic development. Mainly when compared to the northern portion of Rio Grande do Sul State, which produces grain due to rich basaltic soil (BOLDRINI, 2009; CRUZ; GUADAGNIN, 2010; ROCHA, 2011).

The immigration process (Italian and German) that began in the mid-19th century, originated in the northern region a distinct economy related to the South. In the North, there was the creation of small properties with very close urban centers, which constituted an expressive urban network (ALONSO, 1986; ETGES, 2010). For several economic historians, the diversified economy production of the northern region of the State is mainly due to German and Italian immigrants. However, it should be noted that when immigrants came to Brazil, they were economically and political supported by the Brazilian government.

In fact, in the 19th century Europe was facing an economic and political instability, especially Germany, which was undergoing a process of National unification that excluded 
a large number of farmers, artisans and others from the working classes. Another determining factor for European immigration was the advance of mechanized manufacturing industrial process that devastated the artisanal production of the continent; forcing the poorest Europeans to come to South America (ROCHE, 1969).

Therefore, two sociocultural scenarios were built in Rio Grande do Sul State: the developed North, colonized by European immigrants in the 19th century (which reaches the 21st century as the main economic region of the state), and the South, occupied in the 17th and 18th centuries by Portuguese and Spanish of military origin, who after decimating the indigenous communities that inhabited the region, started to have a strong attachment to extensive cattle production.

The formation of the economic process in the northern region of Rio Grande do Sul State was marked by the creation of small and medium properties that basically produced colonial products (vegetables, legumes, grains, etc.). This provided the basis for the beginning of an industrialization process. In contrast, the southern region was mainly formed by the occupation of large tracts of land, which induced to the extensive cattle rising areas (ROCHA, 2011). As a result, in the early 21st century, the southern region presented few economic alternatives and a wealth concentrated in families of landowners, mostly descendants of Portuguese and Spanish military who occupied the region between the 17th and 19th centuries.

Specifically after the 1980s, the political, economic and social aspect of the southern region gave rise to a more concrete discussion of the so-called "crisis of the southern economy" (CORONEL; ALVES; AMARAL, 2007). That was a consequence of some macroeconomic processes, such as the cattle ranching and agriculture crisis, the implementation of Mercosur and especially the impact of neoliberal economic openness, dictated in Brazil by the international circumstances of the world's economy globalization (ETGES, 2010; ROCHA, 2011).

SCHNEIDER, 2001 mentions that the 1980s are likely to be remembered in the future as the period that marked changes in the agriculture structure and social life in the rural world in many agrarian regions in different countries. As a consequence, in the mid1990s, a Special Commission was created in the Rio Grande do Sul State to deal with the development of the southern region. It should be emphasized that the difference in economic performance of the two regions had begun in the 1930s, when the northern region had already reached $61 \%$ of the State's Gross Domestic Product (GDP), which got much worst, reaching in 2003, 78.6\% (FEE, 2006). 
Analyses of development policies for the region in the last two decades predict that, although it is recognized that the regional issue in Rio Grande do Sul is more complex than a simple dichotomous view between the South and the North, giving rise to more detailed policies that aim to find more effective solutions, it should be noted that the evaluation of the policy trajectory focused on this scenario still needs to be detailed (CARGNIN, 2014, p. 54).

Comparing economic and social data between the two regions, per capita income in the period $1939-90$ increased $345.28 \%$ and $559.02 \%$ in the South and North, respectively. Regarding the production volume of the 20 main agricultural products in 1997, the South contributed only $15.7 \%$. According to data from the Foundation for Economics and Statistics, the GDP of the southern region represented only $19.97 \%$ in 1996 against $80.03 \%$ of the North, in 2006 this scenario is even worse, since it represented only $10.3 \%$. The average income of formal workers in the 1990s in the North was $R \$ 1,158.01$, while in the South was $\mathrm{R} \$ 790.46$. The industrial establishments of the southern region accounted for only $5.7 \%$ of the total of Rio Grande do Sul State (FEE, 2006).

After the second half of 20th century, due to economic needs or pressure of land policy, the stability is disrupted, resulting in reduction in the vegetation cover and degraded fields with high biodiversity loss. These degraded fields have reduced meat productivity and offer the opportunity for the third cycle of environmental transformations to advance over Pampa biome: industrial agricultural activities (CRUZ; GUADAGNIN, 2010).

The replacement of animal production for an agroecosystem matrix was $60 \%$ of the original area in 60 years. Consequently, in the early years of 21 st century only $40 \%$ of the original area remains, in which only $22 \%$ are native fields, $5 \%$ forests and $13 \%$ mosaics of fields and forests. This transformation was on a scale of decades, which this biome had never suffered in thousands years. According to Cruz e Guadagnin (2010) this disturbance is so intense that completely decharacterizes the field system.

Corn cultivation grew between 1940 and 1996, from 1.4 to 11.8 million tons in the region. In the same period, soybean production increased from 1,530 to 10,7 million tons and wheat production from 95,000 to 1,4 million tons. These crops were implemented mainly in the Pampa native grassland areas. In contrast, the rice production was placed in the floodplains, also causing a significant transformation and one of the most fragile ecosystems of the Pampa, the wetlands (BEATRIZ; CARVALHO; OZORIO, 2007; GUADAGNIN et al., 2009) 
The advance of grain culture over Pampa Biome was a consequence of the Green Revolution expansion in Brazil, which consolidated the integration between agribusiness and grain production. Mainly because the return rates per unit of area was more compensating than traditional cattle ranching. In few decades, the fields of the Pampa region that initially had used for cattle ranching, ended up being generally rented for business agriculture.

Between 1990 and 2010 cattle ranching stabilized at 4-5 million animals. During the same period, grain production expanded from 300,000 to 500,000 hectares (IBGE, 2010). Overbeck et al. (2015) mention that this stabilization in the animal's number was only possible because there was an increase in cultivated pasture, which was catastrophic for the biome biodiversity.

The introduction of exotic species into the native fields was perhaps the most severe transformation in Pampa biome. The most invasive species that was introduced in the 1950s was the Capin anonni. This species demonstrated enormous invasive potential. It is estimated that at least 3,100 million hectares have been invaded (GOULART et al., 2009), leading to an unprecedented loss of forage quality and biodiversity in the biome. Data collected by Guadagnin et al. (2009) in Brazilian, Argentinean and Uruguayan Pampas recorded the presence of 356 species that established populations in native grasslands. Most of them were introduced intentionally.

The last decades of the 20th century marked a new phase in the region economy. The depletion of the traditional extensive livestock model and a progressive devaluation of land by landowners, which made it attractive to forestry companies; that would become the new economic and social actors in the region (BINKOWSKI; FILIPPI, 2009).

In the 2000s, the area of forestry increased by $30 \%$ in Rio Grande do Sul State in only 10 years, mostly over the Pampa Biome. The largest investor in the region was the company Stora Enso, which acquired 50,000 hectares for eucalyptus planting (ETGES, 2010; SUERTEGARAY; SILVA, 2009). The forestry expansion has produced a huge landscape transformation by introducing a new element in the matrix - the presence of forest massifs (CRUZ; GUADAGNIN, 2010).

Another consequence of these socioeconomic and environmental transformations were cultural changes with a process of deterritorialization of the region's gauchos (exformer employees), accompanied by the creation of a new rural business community (CHELOTTI, 2010). Thus, the objective basis on which the economic, cultural and political transformation that was built was reconfigured by the dynamics of the classical 
developmental proposals of the capitalist system, with the replacement of the ranch (rancher) by the farm (rural grain companies). And then, between the late 20th and early 21 st centuries, by eucalyptus and pine forestry companies. The reproduction of capital has always been the focus of development policies said as a "solution" to remedy social inequalities in the SRS. These misunderstandings keep repeating, despite the well-known history.

\section{DEVELOPMENT POLICIES FOR BRAZILIAN PAMPA BIOME}

The "crisis of the southern" was in fact a discourse "refined" and known by other names at different times, which existed in the region for at least 150 years (ROCHA, 2011). These "southern revolutions" of the XIX century were not real revolutions, because they did not intend to change the status of the dominant class (farmers) or even provoke some improvement in the social conditions of the poorest.

The "Farroupilha" in 1835, the "Federalist" in 1893 and the "Liberal" in 1923, were mere protests of the agrarian elite landowner and cattle rancher who dominated economically and politically the regional society, against the low rate of profitability of their activities (cattle and charque, basically). However, these speeches were incorporated, ingenuously, by other members of the local society, mainly the poorer and uninformed (MONASTERIO, 2002; OLIVEN, 1989, 2006; ROCHA, 2011).

According to Cargnin (2014), it was in the 1980s that the SRS became a region considered underdeveloped under conditions equivalent to the northeast of Brazil, and for this reason it was necessary to allocate public resources in addition to development strategies encouraged at different levels (national, regional and municipal).

As a result of the political movements, the State began to develop public policies and instruments, with the ultimate goal of resuming economic growth in the region, encouraging its productive reconversion. Etges (2010, p. 176) considers that the SRS, as a sub-regional space inserted in the border region between Brazil, Uruguay and Argentina, is characterized by a marked process of loss of economic dynamism. This process resulted from difficulties of insertion in the expansion cycles of Brazilian economy. From the 80s, the crisis that began in the 30s with the end of the cycle of "charqueadas" in Pelotas city, has been deepened. 
Two factors collaborated to strengthen the discourse of the backwardness and abandonment of the SRS region: 1) the relative and rapid economic advent of the northern region of Rio Grande do Sul State between the end of the 19th century and the beginning of the 20th; 2) the consolidation of the southeast of the country as the most industrialized and developed region of Brazil in the first decades of the 20th century.

According to Albuquerque (2012, p. 60) this institutional and credit structure, initially contemplated the Northeast, later extended to the Midwest and North, based on the geopolitical discourse of the demographic gaps occupation, but the South had its own bank to receive transfers of federal public funds (the Regional Development Bank of the Extreme South - BRDE).

These demands are part of a context that has always been on the agenda of the capitalist elites, in which the solution is to blame the State for the exhaustion or lucrative inability of its business. In recent years, these protests in the region have been masked in some regional development projects, projects considered social and endogenous.

Albuquerque (2012) highlights, as denunciation, how this perverse logic of capitalism was incorporated into the elitist strategies in Brazil. It was foreseen by Karl Marx (2014), who links the logic of financial reproduction to the strategies of private property maintenance.

The developmental agenda of the elites in regions considered peripheral such as SRS is constantly searching for policy strategy and government subsidies to facilitate the technical conditions for their own economic reproduction. Thus, the discourses on regional development seem to strengthen some new regional social actors, such as class entities, non-governmental organizations, cooperatives, etc., but, in the case of SRS, do not fail to represent the interest of large landowners, making the financial and public funds an increasingly disputed arena.

With the growing centrality of public policies and funds for the recomposition of the regional social structure, the redefinition of the regional elite by the monopoly on access to credit becomes as important as the monopoly on land ownership (ALBUQUERQUE, 2012, p. 58). Developmental policies for SRS have never ceased to be linked to the interests of large landowners who produce commodities, or to national demands, such as the charque in the 19th century, or to international demands, as meat and cellulose in the 20th and 21st centuries, respectively.

Cargnin (2014, p. 54) considers that the region is characterized by the concentration of traditional activities related to the cattle ranching and, more recently, 
rice, fruit and forestry. The "crisis" began with the end of charque cycle between the end of the 19th century and the beginning of the 20th, in which the Pampa biome enters into a process of economic degeneration that takes on increasing proportions over the decades; after the charque cycle, the region's economic agents were unable to find new economic mechanisms, not even in processes of agricultural industrialization.

Therefore, the roots of the SRS crisis were the lack of capacity of its economic agents (landowners, ranchers, rice farmers) to create mechanisms to promote effective development in the region. Without economic alternatives, the real losers were the poorest, while the region's landowners and capitalists have always found other ways to reproduce their wealth; in recent decades, the alternative was to sell their large areas to forestry companies.

In this context, we can already conclude in this section that the development proposals for the SRS, its evolution and the problems that determined it, lead SRS to a position of lesser economic importance in Rio Grande do Sul State and Brazil, both in social and economic terms, with few effectively sustainable perspectives. The main responsible were: 1 ) the elite that owns the lands in the region, which their ancestors generally usurped from the indigenous people; 2) the capital obtained through constant government financing; 3 ) and the political power that resulted from the first two factors.

\section{EUCALYPTUS PRODUCTION POLICY IN SOUTHERN BRAZIL}

The first fact that stimulated the forestry as an activity in Rio Grande do Sul State, was Decree No. 43.493, December 10, 2004, which contained the government's decision of the time (Germano Rigotto) to institutionally promote the production of forests (Eucalyptus and Pines in particular) (RIO GRANDE DO SUL, 2004). Therefore, it was created a political space of management, through an institutional decree, designed to encourage a new production base in the SRS that aimed to combat the poor economic performance of the region.

The Rio Grande do Sul Forestry Productive Arrangement Management Committee ("Arranjo Produtivo de Base Florestal" - APB Florestal) became the first public management policy space that explicitly intended to encourage investments in the expansion of forestry activity. 
With APB Florestal, the government became a partner of the large transnational pulp production companies that had the purpose of implementing eucalyptus plantation mega-projects to produce pulp for paper production. The governmental role was to create adequate infrastructure for the flow of production, as well as to stimulate, through financing, small and medium-sized companies that aimed to invest in the forest planting in SRS.

The three major companies in the sector, which had already been operating in Brazil were: Aracruz Celulose, Votorantim Celulose, and the Swedish-Finnish multinational giant Stora Enso (considered one of the oldest companies in the world, with uninterrupted operations since 1288). All of them were part of this project. In this context, a policy of integrating public and private agents that had the explicit intention of fostering the forest production in the State was formed. In other words, the government allied itself with the interests of large economic groups, which intended to definitively exploit the ecological resources of Pampa biome.

From the political articulations of economically powerful groups and the connivance of the State government, a development project was constituted that formed a new production chain for the SRS, coordinated by the APB Florestal and following the logic of exploitation of the natural resources of the region. The configuration of the agents that compose this Productive Arrangement (Table 1) illustrates the interests of the developmental and concentrative logic of this policy.

Barcelos (2012) commented that the "Pro-Expansion Coalition of Forestry" is an example of conchavos in defense of an economic sector, a typical Advocacy Coalition Framework, which supposedly aimed to reduce regional inequalities through the implementation of a developmental strategy, with the protagonism of the same actors that led the SRS region to an economically unfavorable situation.

Two main factors that identify a typically "framework" coalition were present in this strategy: 1) an articulation between a range of social and economic agents who shared the same economic and political ideology, developmentalism, which considered the only possible form of development for SRS; 2) the joint action, to place this ideological perspective in a political design that could be embedded in the discourse in almost all segments, as well as in the effective action with allocation of resources through financing agencies. 
Table 1 - Agents that compose the Forest Based Productive Arrangement

\begin{tabular}{|c|c|}
\hline Goverment agency & Non-governamental organization \\
\hline Gabinete do Governador & Federação dos agricultores do RS (FARSUL) \\
\hline $\begin{array}{l}\text { Secretaria do desenvolvimento e assuntos } \\
\text { internacionais }\end{array}$ & Federação das Indústrias do RS (FIERGS) \\
\hline Secretaria da agricultura e abastecimento & Federação do Comércio (FECOMÉRCIO) \\
\hline Secretaria do Meio Ambiente & $\begin{array}{l}\text { Federação das Associações Comerciais } \\
\text { (FEDERASUL) }\end{array}$ \\
\hline Secretaria da Fazenda & $\begin{array}{l}\text { Federação dos Trabalhadores na Agricultura } \\
\text { (FETAG) }\end{array}$ \\
\hline Secretaria do Planejamento & $\begin{array}{l}\text { Federação das Cooperativas agropecuárias } \\
\text { (FECOAGRO) }\end{array}$ \\
\hline Secretaria da Ciência e Tecnologia & Associação dos Fumicultores do Brasil (AFUBRA) \\
\hline Caixa RS & Associação Gaúchas de Reflorestadores (AGEFLOR) \\
\hline $\begin{array}{l}\text { Gabinete da Reforma Agrária e } \\
\text { Cooperativismo }\end{array}$ & SEBRAE/RS \\
\hline \multirow[t]{3}{*}{ Federação dos Municípios (FAMURS) } & $\begin{array}{l}\text { Sindicato das Indústrias de Madeira } \\
\text { (SINDIMADEIRA) }\end{array}$ \\
\hline & $\begin{array}{l}\text { Sindicato das Indústrias de Papel e Papelão } \\
\text { (SINPASUL) }\end{array}$ \\
\hline & $\begin{array}{l}\text { Associação dos Fabricantes de Móveis RS } \\
\text { (MOVERGS) }\end{array}$ \\
\hline
\end{tabular}

Fonte: Decrete no 43493/ RS.

The idea that forestry would support the SRS development spread in several places, especially in the press of the region. The companies linked to the sector started a large advertising campaign whose main focus was to promote eucalyptus production as a big business for all social segments. The action of this coalition occurred in various places, where it was possible to highlight and disseminate the bases of this essentially positive image, without any environmental context more seriously analyzed.

This strategy in the 2000s had great social support, given the levels of unemployment that the region was experiencing. Other factors, such as environmental issues, for example, were considered less important. At the time, the economic stagnation and unemployment were the region's great "enemies". The developmental vision of APB Florestal members is clearly seen in the strategies that disseminate it, and this is how the basis of conflict related to the environmental problems was formed. 
Another important factor that must be highlighted is the disclosure by the big companies of the sector: Votorantim, Aracruz and Stora Enso. They claimed that industrial investments in forestry production would require planting over half a million hectares of eucalyptus in the region. The news that spreaded this huge number of hectares caused a reaction from environmentalists who had not yet appropriated more specifically about the problem.

Thus, it was necessary to create an alternative political image for the region, different from the developmental logic in which forestry had been treated. Finally, the need for the forestry activity regulation led to the game of pressures to stablish the expansion limits of large plantations, this instrument was the Forestry Environmental Zoning (ZAS).

The Environmental Zoning of Forestry in Rio Grande do Sul (ZAS), explicitly reflects the game of interests between sustainable parsimony versus developmental politics. In one side was the economic interests of large forestry companies, which intended to grow eucalyptus and pine without much restriction in SRS, but using green marketing (certifications), to expand their trading strategies in markets where this requirement was needed (hence the funding from ZAS by AGEFLOR). In the other, was environmental groups and public bodies (FEPAM, SEMA, FZB) that questioned the need to create specific legislation for this new activity in the State.

The ZAS objective was to be a management tool that would enable the integrated assessment the environments vulnerability in relation to the implantation of arboreal crops, identifying suitable agricultural areas, but respecting the sustainability constraints of the natural resources. However, from the organization of the team to the data collection for analysis, there were long months of discussion, causing the debate on the new licensing instrument to have several conflicts.

One of the principal points of disagreement and the most controversial in the ZAS elaboration was about the definition of the management unit: the watersheds (Bacia Hidrográfica - BH) or the landscape unit (Unidade de Paisagem Natural - UPN). After many debates the UPN was defined in the justification that it takes into consideration the sectorization of the territory of the Rio Grande do Sul State in homogeneous regions, defined through criteria that reflect the original physiognomic and landscape characteristics.

In summary, it can be considered that the incentive policy for forestry production in SRS was a strategy of actors who had (and still have) conviction that this is an effective 
project for improvement for local society. That is the reason why it was an articulated strategy between political and economic sectors with legitimate expectations that this was an effective strategy to change the history of economic development in the region.

According to the AGEFLOR (2017), Rio Grande do Sul had 781.000 (ha) of forestry monoculture in 2017, but 417.931 (ha) only in 20 municipals most of them in Pampa biome, how we can see in Figure 2. It is important to say that all this production began in 2006 with the arrival of the forestry companies in the State.

Figure 2 - Forestry Monoculture distributed by Rio Grande do Sul until 2017

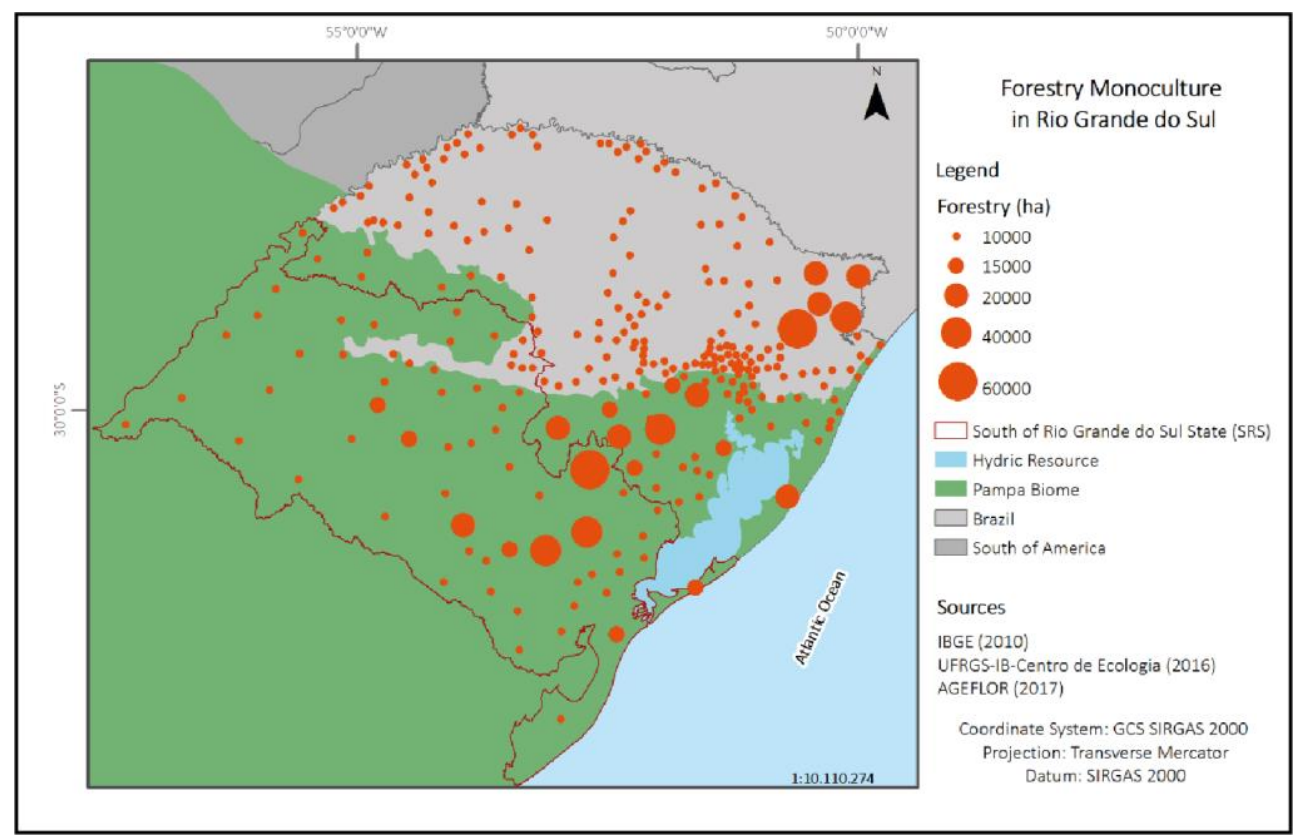

Source: Elaborated by Author. UFRGS-IB-CENTRO DE ECOLOGIA (2016); IBGE (2010); AGEFLOR (2017).

\section{THE ENVIRONMENTAL ISSUE AND AFFORESTATION OF PAMPA BIOME}

The reaction of the environmental movements to the APB Florestal started to be more effective in 2005 , the context of the reaction to the eucalyptus and pine cultivation megaprojects in SRS was the preservation of the biodiversity of the Pampa biome. For this group, it was necessary to prevent mega cultivation and find political mechanisms to control the expansion of forestry in the Pampa, since forest production could not be avoided anymore (BARCELOS, 2012).

The initial issue was the use of the term reforestation, which was immediately contested by these agents; the second was to reject the positive connotation that the crop 
proposals had in the early 2000s regarding the preservation of the region's natural resources. It is worth noting that in the first documents of the APB Florestal coalition policy, the environmental preservation of Pampa biome, widely publicized by the majority press, was one of the main reasons for optimism in the eucalyptus plantation.

Another denunciation of this group was the lack of knowledge about the ecological aspects of Pampa, as well as the history of the harmful consequences that the introduction of exotic species had on the ecosystem of this biome. These species are often better competitors than native species because of the absence of natural enemies. An emblematic example was the introduction of the African grass known popularly as capimannoni (Eragrostis plana). When this species is installed, its population increases every year and, over time, and ends up eliminating the rest. If its invasion is not detected at the beginning, the elimination is very difficult (BARCELOS, 2012).

The group that started to participate in the policy of reaction to the implementation of forestry in the region claimed that it was not correct to say that the eucalyptus and pine plantations could serve to protect Pampa, much less that this strategy was linked to the environmental perspective of sustainable production. In this context, the term "green desert" appears, which despite being the target of numerous attacks by representatives of the APB Florestal, symbolically represented the effective threat of changing in the landscape of Pampa biome.

However, this group linked to preservationist movements, even if they generally contested the policy of the APB Florestal, they did not constitute a coalition group. The strategies, in the most varied forms (press of cities in the region, dissemination of scientific articles on the subject, interviews in local radio, etc.) were to disseminate information that could affected the positive image that had already been constituted on forestry, such as the generation of employment and development for the region, a speech that again propagated a development strategy imposed.

The production of eucalyptus monocultures impacts generated were highlighted in relation to the preservation of the remaining biodiversity of Pampa biome; with the use of pesticides that the activity requires; and the need for water, which could affect the water availability by the maintenance of Pampa landscape, which, despite the monoculture of grains, remained with stable socio-environmental aspects. This alternative image emphasized the possible risks and threats that the expansion of plantations could bring to Pampa biome and affirmed the importance of creating limits for the management of the 
activities. The consensus conclusion was that the rules were necessary in view of this new regional production strategy.

Forestry policy should have a regulatory instrument that indicates, from the point of view of environmental protection, where plantations would be allowed, and where they should be restricted or, in the case of certain areas, even prohibited. It was a question of analyzing, not only with productive economic expectations whether forestry should be an activity subject to environmental licensing in Pampa biome (BARCELOS, 2012, p. 87)

The movements that proposed greater parsimony in the use of Pampa ecological resources emphasized that there was something strange about the policy of forestry companies. Mainly because it did not seem logical that in Brazil the Amazon forest should be cleared to expand cattle ranching areas and thousands of hectares of native grassland be eliminated in southern Brazil to produce grain for export or plant exotic trees (OVERBECK et al., 2007; OVERBECK; PODGAISKI; MÜLLER, 2015; PILLAR; ANDRADE; DADALT, 2015).

The biodiversity of Pampa biome consists of a diversified number of plant and animal species, which have historically formed, in thousands of years, a complex network of interactions involving, systematically, organisms and factors such as soil, relief, climate and pastoral management. This constitution of Pampa is not a place "useless," "poor," "lifeless," as often propagated by developmentalist economic agents; on the contrary, the ecosystem services of the biome are immeasurable and not well known (PILLAR; ANDRADE; DADALT, 2015).

In this way, it should be understood that the maintenance of Pampa provides many ecosystem services, such as the regulation of water and potable water supply, the production of fodder for cattle ranching, the maintenance of pollinators and predators of agricultural pests, the tourism potential (rural and adventure tourism), the maintenance of carbon stocks in the soil to mitigate global climate changes and as well as the maintenance of landscape aspects in the region for future generations (OVERBECK et al., 2007; PILLAR; ANDRADE; DADALT, 2015).

According to Boldrini (2009), in "poor" analyses, Pampa biome can be confused with simpler formations, dominated by a single type of grassland (Graminea). However, in more accurate analyses, it is noted that Pampa is an ecosystem as complex, or even more complex than a forest (Atlantic Forest or Amazon, for example), with several plant formations. In Pampa its systemic integration with the fauna and flora, constitute its biological wealth. The biota of the biome is peculiar and incomparable. 
As for social aspects, which was the focus of the APB Florestal, environmentalists emphasized that silviculture generated side effects to the economic development as: migration of workers, both those who come to the region in search of work (precarious and temporary), as well as those linked to cattle raising activities; expulsion of small family farmers, who are either attracted to activities linked to forestry and or are literally "surrounded" by forestry activity and had moved to urban centers; besides the impacts on roads in the region, with the increase in the number of trucks, where the already precarious roads inside the municipalities are almost impossible to drive. It is important to note that the condition of the roads has always been a critical point for the (nondevelopment of the region. This fact came to be relativized in the discourses that defended the eucalyptus plantations.

The different conceptions of the development forms for Pampa biome are reflected in the proposals of different social groups, and are showed in Figure 3, both reflecting the different ways of perceiving eucalyptus production in SRS. Figure 3(a) is a presentation slide "Planted forests: a national wealth and a strategy for the development of RS" by the Brazilian Forestry Society, which propagates the solution for the future of the region in forestry production, while Figure 3(b) is the cover of a "Via Campesina"publication, which makes a counterpoint on the cultivation of eucalyptus in the region, both from mid-2006. Via Campesina is an international peasant's organization composed of social movements and organizations from all over the World. This organization aims to articulate the processes of social mobilization of rural communities at the international level.

Figure 3 - Examples of different conceptions for the Pampa biome developments; Figure 2 (a) by Brazilian Forestry Society; Figure 2 (b) by Via Campesina

(a)

"As pessoas que plantam florestas acreditam no futuro"

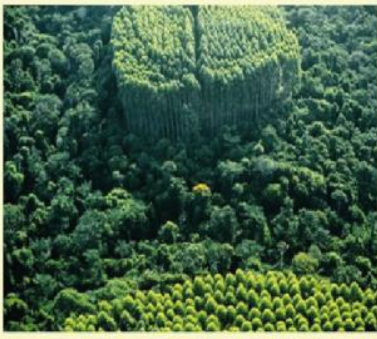

(b)

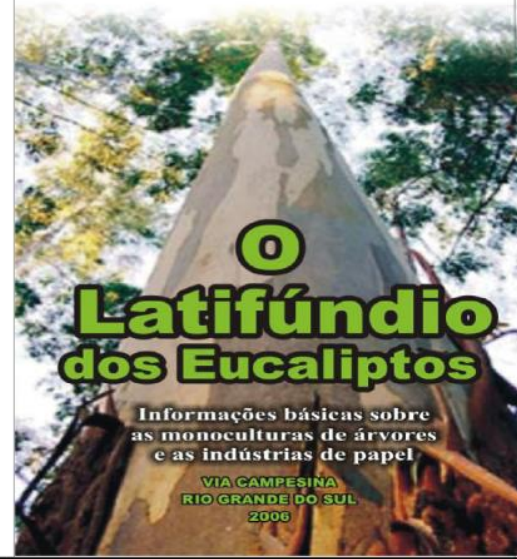

Source: SOCIEDADE BRASILEIRA DE SILVICULTURA (2006); VIA CAMPESINA (2006) 
In this context the use of the term forest is equivocal because from the ecological point of view the cultivation of eucalyptus for commercial purposes does not have the variety of species necessary to be called forest. A forest is a complex system that regenerates itself and that has soil, water, microclimate, energy and also a wide variety of plants and animals in mutual relation. On the other hand, a commercial plantation is a cultivated area whose species and structure have been dramatically simplified to produce only a few products, i.e. wood, firewood, resin, oil or fruits. Unlike what happens in forests, a plantation requires a constant and broad human intervention (BINKOWSKI; FILIPPI, 2009).

There is no reason to believe that the policy of implementing silvicultural monocultures will not cause ecological degradation in Pampa biome, an ecosystem that has been evidently without vocation for this type of productive strategy (SANTOS; TREVISAN, 2009).

\section{EUCALYPTUS CULTIVATION AND THE ENVIRONMENTAL IMPACT}

The genus Eucalyptus L'Herit, popularly known as "eucalyptus", has over 600 species originating from Australia, Tasmania, Papua New Guinea, Timor and Indonesian archipelagos (MARCHIORI; SOBRAL, 1997). It was introduced in Brazil approximately 142 years ago, but as a commercial practice began in the early 20th century. It is worth mentioning that eucalyptus is not part of the Latin America's native flora and is therefore considered an exotic species throughout the territory (SANTOS; TREVISAN, 2009).

Santos and Trevisan (2009) reported that the power of the pulp industries in Brazil, allied to the mainstream media (especially the biggest newspapers of the State), the ideology of developmental interests of state and municipal governments, and the lack of knowledge about the eucalyptus plantations expansion consequences, are factors that cause environmental issues related to water use, biodiversity loss and landscape impacts in Pampa biome (OVERBECK et al., 2007; OVERBECK; PODGAISKI; MÜLLER, 2015).

The pulp industries, government and media representatives often accuse environmentalists of conspiring against the 'Development Project'. This attitude is clearly an element used to dispel the attention of environmental issues relative to the conversion of Pampa biome into tree plantations and to degrade the researchers' image in society. Unfortunately, biologists and ecologists do not have economic power as large companies, 
which makes it difficult to bring knowledge from Academy to society (HASENACK; CORDEIRO; COSTA, 2007; SANTOS; TREVISAN, 2009).

Some studies around the world (FARLEY; JOBBÁGY; JACKSON, 2005; JACKSON et al., 2005; JOBBÁGY et al., 2006) have proven that the gaucho is starting to observe that eucalyptus plantations have the capacity to dry the wetland (SANTOS; TREVISAN, 2009). According to Jobbágy et al. (2006), these monocultural crops on fields such as Pampa biome with shallow soils tends to prevent the rainwater to recharge the sources and reservoirs that exist in the region. Mainly because the groundwater is close to the surface and plantations are located in large areas and in small spacings (over 1,100 plants per hectare).

Research results found on all continents show that arboreal, eucalyptus and pine crops in particular use more water resources than the endemic grassland and shrubbery of each region, leading to ecological and socioeconomic impacts. At four continents around the world, the establishment of arboreal crops over bush-shrub systems has dramatically reduced stream flow between $39 \%$ and $52 \%$, depending on the age of planting.

About $13 \%$ of the streams have completely dried up and eucalyptus plantations have dried more streams than Pine plantations. Considering only impacts on rural areas, eucalyptus was also the tree crop with the greatest impact on streams, since it reduced the water flow in this system by $75 \%$ (compared to $45 \%$ caused by Pine cultivation) (FARLEY; JOBBÁGY; JACKSON, 2005). In Argentina, water loss from plant transpiration in Eucalyptus grandis crops averaged $80 \%$ higher than in native fields, varying with its age: in both the first years after planting, arboreal crops have already outgrown the evaporating native field, and within four years of planting, they have doubled water loss (SANTOS; TREVISAN, 2009).

Eucalyptus and pine crops also have a higher demand for soil nutrients than native fields in Pampa biome. This higher consumption causes chemical changes in the soil, which compromises its fertility. In addition, tree planting in rural systems such as Pampa, leads to the phenomenon of salinization. Since the tree roots remove calcium, magnesium and potassium from the soil, they concentrate huge amounts of salt (sodium) in this soil.

In the salinization phenomenon, the environmental impact occurs due to great differences between the field system and the arboreal crops, because the herbaceous plants roots cannot have access to the deeper water reserves, whereas trees have. Jobbágy et al. (2006) comment that tree crops absorb a large amount of water deposited in the soil, thus lowering the local level of this resource and causing salinization. 
Therefore, there is a redistribution of groundwater from neighboring areas to the tree planting area in order to balance the water level.

Studies of eucalyptus cultivation in Argentine Pampa show that there have been processes of soil and groundwater salinization. In these places, the type of crop increased by up to 30 times the salt concentration that are found in native fields. In some cases, the salinity of water exceeded by up to $25 \%$ that commonly recorded in seawater, which exceeds the limit considered safe for human consumption (JACKSON et al., 2005; SANTOS; TREVISAN, 2009).

Finally, Gomes and Trevisan (2015) highlight an important argument to controvert the fragile environmental principles of eucalyptus advocates. They mention that it is evident that all native plants use water and soil nutrients. However, it should be understood that typical Pampa herbaceous and shrub plants consume less than exotic tree plants.

Eucalyptus advocates usually distort this issue by saying that the native forests (also present in Pampa) consume more water than the native field, thus making the same damage attributed to eucalyptus (reduction of water availability, acidification and sanitization of water and soil). Nonetheless, this is not entirely true. In fact, forests consume more water and nutrients than fields, but the native forests are composed of slow growing species, which means that they grow at a much lower rate than eucalyptus, using less natural resources. In addition, many native forest species are not active yearround, as they lose their leaves in fall/winter seasons. Therefore, during this period, plant dormancy serves as a natural rest for the environment.

\section{CONCLUSIONS}

The current development stage of SRS is the result of a productive logic imposed on the region for over three centuries. The military origin of the occupation between the 17th and 18th centuries made the extensive ranching to be incorporated into the regional economy, which prevailed almost exclusively until the mid-20th century. Grain cultivation that also emerged in the middle of this century, reflected the exhaustion of this model and the need for more areas for rice and soy cultivation by grain producers in the northern region of the State. Eucalyptus and pine plantations, which appeared at the end of the 20th Century, was due to the interest of large international corporations, seeking 
cultivation areas in which the price of the land and the edaphoclimatic conditions were widely favorable to increased profitability.

It can be concluded that all development strategies for the SRS region followed a policy of favoring the reproduction of capital. The aggravating of the forestry policy are the landscape changes in the natural resources of the region, besides being unprecedented (since in Pampa there were never trees), there is no possibility of economic benefits being reversed by an increase in the number of quality jobs, and even in the benefits of infrastructure improvements. In fact, it is a developmentalist policy that favors only agents outside the region. In other words, the local society has been deceived into the false expectation that exogenous strategies can bring the solution to the lack of socioeconomic expectations to SRS.

The lack of knowledge about the environmental impacts of forestry activity in the Pampa biome cannot be considered, since researches in similar biomes in which natural resources have been severely affected are already well-known. Even though, the precautionary principle states that in the absence of scientific certainty, the existence of a risk of harm should ban the implementation of any strategy in order to prevent a possible damage. The socioeconomic aspects (which were one of the promises to relativize the possible impacts of forestry activity), are still little perceived in the region. The employments generated in tree plantations are mostly painful and temporary activities with low salaries.

Finally, Marques (2016) mention that there is no sustainable capitalism because there can be no sustainability when: (1) the legal order ensures that decisions about strategic investment flows originate from a small group of people and serve their interests; (2) the reason of these investments is to expand remuneration/reproduction of capital. Future studies should focus on the employment offered to forestry workers; the impact of tree monoculture on the fauna and flora of Pampa biome and its environmental weaknesses; family livestock as a strategy for support small farmers; the consequences of the Forest Savings Project, agrarian reform settlements and forestry; the impacts of afforestation on Quilombola culture; the sustainable alternatives for the region (rural tourism, wine-growing, fruit growing, etc.), among others.

\section{ACKNOWLEDGMENT}

Thanks to reviewers, collaborators and development agencies. 


\section{REFERENCES}

AGEFLOR. A Indústria de Base Florestal no Rio Grande do Sul. Porto Alegre.

ALBUQUERQUE, E. S. De. A PRODUÇÃO DA MISÉRIA NA METADE SUL GAÚCHA A PARTIR DA APROPRIAÇÃO PRIVADA DOS FUNDOS PÚBLICOS. Sociedade e Território.2012; 22 (2). Disponível em: https://periodicos.ufrn.br/sociedadeeterritorio/article/view/3495.

ALONSO, J. A. . Evolução das desigualdades inter-regionais de renda interna no Rio Grande do Sul 1939-70. 1986, Porto Alegre.

BARCELOS, M. Processos Sociais, Construções Discursivas e "Imagens de Política Pública|" na Construção da Política de Silvicultura no Rio Grande do Sul. Plural (São Paulo Online). 2012; (19): 83.

BEATRIZ, A.; CARVALHO, P.; OZORIO, C. P. Avaliação Sobre Os Banhados Do Rio Grande Do Sul, Brasil. Revista de Ciências Ambientais. 2007; 1 (2): 83-95.

BINKOWSKI, P.; FILIPPI, E. E. Os Discursos sobre o Desenvolvimento frente às Políticas Públicas de Incentivo à Implantação de Cultivos de Eucaliptos no Estado do Rio Grande do Sul. Raízes (UFPB). 2009; 27:105-206.

BOLDRINI, I. A flora dos campos do Rio Grande do Sul. In: PILLAR, V. de P. (Ed.). CAMPOS SULINOS, CONSERVAÇÃO E USO SUSTENTÁVEL DA BIODIVERSIDADE. MMA ed. Brasília/DF. p. 63-77.

CARGNIN, A. P. Desenvolvimento Da Metade Sul Do Rio Grande Do Sul. Revista de Desenvolvimento Regional REDES. 2014; 19 (2): 53-76.

CHELOTTI, M. C. Reterritorialization and Territorial Identity. Sociedade e Natureza. 2010; 22 (1): $165-180$.

CORONEL, D.; ALVES, F.; AMARAL, M. Notas sobre o processo de desenvolvimento da metade sul e norte do estado do Rio Grande do sul: uma abordagem comparativa. Perspectiva Econômica. 2007; (21): 4835-4839. Disponível em: http://revistas.unisinos.br/index.php/perspectiva_economica/article/view/4339.

CRUZ, R. C.; GUADAGNIN, D. L. Uma pequena história ambiental do Pampa: proposta de uma abordagem baseada na relação entre perturbação e mudança. In: COSTA, B. P. Da; DIECKEL., M. E. G. (Eds.). A sustentabilidade da Região da Campanha-RS: Práticas e teorias a respeito das relações entre ambiente, sociedade, cultura e políticas públicas. Santa Maria: UFSM, PPG Geografia e Geociências, 2010. p. 155-179.

DEAN, W. A ferro e fogo. 1st. ed. São Paulo: Companhia das Letras, 1996.

ETGES, V. E. Desenvolvimento regional: uma análise da metade sul do Rio Grande do Sul, Brasil. Novos Cadernos NAEA. 2010; 13 (2): 169-186.

FARLEY, K. A.; JOBBÁGY, E. G.; JACKSON, R. B. Effects of afforestation on water yield: A global synthesis with implications for policy. Global Change Biology. 2005; 11 (10): 15651576. 
FEE. PIBs dos Municípios gaúchos. 2006. Disponível em: https://www.fee.rs.gov.br/indicadores/pib-rs/municipal/apresentacao/. Acesso em: 20 ago. 2006.

GAUTREAU, P. Forestación, territorio y ambiente. 25 años de silvicultura transnacional en Uruguay, Brasil y Argentina. 1st. ed. Montevideo: Trilce, 2014.

GOULART, I. C. G. dos R. et al. CONTROLE DE CAPIM-ANNONI-2 (Eragrostis plana) COM HERBICIDAS PRÉ-EMERGENTES EM ASSOCIAÇÃO COM DIFERENTES MÉTODOS DE MANEJO DO CAMPO NATIVO. Planta Daninha. 2009; 27 (1):181-190.

GUADAGNIN, D. L. et al. Árvores e arbustos exóticos invasores no Pampa: questões ecológicas, culturais e sócio-econômicas de um desafio crescente. In: PILLAR, V. de P. (Ed.). CAMPOS SULINOS, CONSERVAÇÃO E USO SUSTENTÁVEL DA BIODIVERSIDADE. Brasília/DF: MMA, 2009. p. 300-316.

HASENACK, H.; CORDEIRO, J. L. P.; COSTA, B. S. C. Cobertura vegetal atual do Rio Grande do Sul. In: (M. Dall'agnol et al., Eds.)II SIMPÓSIO DE FORRAGEIRAS E PRODUÇÃO ANIMAL. 2007, Porto Alegre. Anais... Porto Alegre: UFRGS, Departamento de Forrageiras e Agrometeorologia, 2007.

IBGE. Censo 2010. 2010. Disponível em: https://censo2010.ibge.gov.br/. Acesso em: 3 ago. 2017.

JACKSON, R. B. et al. Trading water for carbono with biological carbon sequestration. Science. 2005; 310: 1944-1947.

JOBBÁGY, E. G. et al. Forestación en pastizales: hacia una visión integral de sus oportunidades y costos ecológicos. Agrociencia. 2006; 2: 109-124.

KARL MARX. O Capital - Livro II. São Paulo: Boitempo Editorial, 2014.

MARCHIORI, J. N. .; SOBRAL, M. Dendrologia das Angiospermas: Mystales. Santa Maria: UFSM, 1997.

MARQUES, L. Captalismo e colapso ambiental. 2. ed. Campinas: Unicamp, 2016.

MONASTERIO, L. M. Capital social e a Região Sul do Rio Grande do Sul. 2002. Curitiba, UFPR, 2002.

OLIVEN, R. G. O Rio Grande do Sul e o Brasil: uma relação controvertida. Revista Brasileira de Ciências Sociais. 1989; (9).

OLIVEN, R. G. National and regional identities in Brazil: Rio Grande do Sul and its peculiarities. Nations and Nationalism. 2006; 12 (2): 303-320.

OVERBECK, G. E. et al. Brazil's neglected biome: the South Brazilian Campos. Perspectives in Plant Ecology Evolution and Systematics. 2007; 9:101-116.

OVERBECK, G. E.; PODGAISKI, L. R.; MÜLLER, S. C. . Biodiversidade dos campos. In: PILLAR, V. .; LANGE, O. (Eds.). Campos do Sul. 1st. ed. Porto Alegre: Rede Campos Sulios, 2015. p. 43-50. 
PESAVENTO, S. J. História do Rio Grande do Sul. 4. ed. Porto Alegre: Mercado aberto, 1992.

PILLAR, V. D. P.; ANDRADE, B. O.; DADALT, L. Serviços Ecossistêmicos. In: PILLAR, V. D. P.; LANGE, O. (Eds.). Os Campos do Sul. Porto Alegre: Rede Campos Sulinos - UFRGS, 2015. p. 117-119.

RIO GRANDE DO SUL. Cria Comitê Gestor de Arranjos Produtivos de Base Florestal do Rio Grande do Sul - APB Florestal2004.

ROCHA, J. M. As Raízes da Crise da Metade Sul: Estudo da formação econômica do Rio Grande do Sul. Jaguarão-RS: UNIPAMPA, 2011.

ROCHE, J. A Colonização Alemã e o Rio Grande do Sul. 1. ed. Porto Alegre: Globo, 1969.

SANTOS, T.; TREVISAN, R. Eucaliptos versus Bioma Pampa: compreendendo as diferenças entre lavouras de arbóreas e o campo nativo. In: FILHO, A. T. (Ed.). Lavouras de Destruição: a (im)posição do consenso. Pelotas/RS. p. 299-332.

SCHNEIDER, S. A pluriatividade como estratégia de reprodução social da agricultura familiar no Sul do Brasil. Estudos Sociedade e Agricultura. 2001; (16): 164-184.

SOCIEDADE BRASILEIRA DE SILVICULTURA. Brasil, Oportunidades para Rotulagem Ambiental. 2006. Disponível em: http://slideplayer.com.br/slide/2262733/. Acesso em: 11 set. 2019.

SUERTEGARAY, D. M. A.; SILVA, L. A. P. Da. Tchê Pampa: histórias da natureza gaúcha. In: PILLAR, V. . et al. (Eds.). CAMPOS SULINOS, CONSERVAÇÃO E USO SUSTENTÁVEL DA BIODIVERSIDADE. Brasília/DF: Ministério do Meio Ambiente - MMA, 2009. p. 42-59.

UFRGS-IB-CENTRO DE ECOLOGIA. Mapeamento da cobertura vegetal do Bioma Pampa: Ano-base 2009., UFRGS-IB-Centro de Ecologia, 2016.

VIA CAMPESINA. O Latifúndio dos Eucalyptos. Rio Grande do Sul. 2006:36. 